\title{
RESISTANCE OF CUCURBITA SPP. TO FUSARIUM SOLANI FOR USE AS ROOTSTOCK ${ }^{1}$
}

\author{
JOICE SIMONE DOS SANTOS ${ }^{2 *}$, RITA DE CÁSSIA SOUZA DIAS ${ }^{3}$, KARINA BRANCO DE ALMEIDA $^{4}$, PEDRO \\ MARTINS RIBEIRO JUNIOR ${ }^{3}$, TIAGO LIMA DO NASCIMENTO ${ }^{5}$
}

\begin{abstract}
Fusarium solani f. sp. cucurbitae (Fsc) is a soil pathogen and the adoption of resistant rootstocks is an effective method of control. Hybrids of Cucurbita spp. are the main rootstock used for watermelon. This study aimed to evaluate the virulence of Fsc race 1 (Fsc1) in three cucurbits and check the reaction of Cucurbita spp. genotypes to the fungus for its use as rootstock. Four experiments were performed. The virulence of Fsc1 in melon, watermelon and Cucurbita spp. was evaluated in experiment I. In experiment two and three the severity of the pathogen in 19 cucurbits was analyzed. And experiment four evaluated the compatibility of these genotypes as a rootstock for watermelon. Cucurbita spp. proved to be more resistant to Fusarium solani $\mathrm{f}$. sp. cucurbitae race 1 than the melon. The high frequency of plants resistant to Fsc1 was found in the genotypes BGC622, BGC620, BGC567, BGC530, BGC186, BGC381, BGC692, BGC082, ES0061 and ES0062. In addition, the evaluated genotypes may be used as watermelon rootstocks, except for the ES530 strain, which was incompatible with the cultivar BRS Opara, but could be used in pumpkin breeding programs, as well as other resistant genotypes.
\end{abstract}

Keywords: Soil pathogen. Grafting. Germoplasm. Cucurbits.

\section{RESISTENNCIA DE CUCURBITA SPP. AO FUSARIUM SOLANI VISANDO O USO COMO PORTA- ENXERTO}

RESUMO - O Fusarium solani f. sp. cucurbitae (Fsc) é um patógeno habitante de solo e a adoção de portaenxertos resistente é um método efetivo de controle. Os híbridos de Cucurbita spp. constituem o principal porta -enxerto utilizado para melancia. O objetivo desse trabalho foi avaliar a virulência de Fsc raça 1 (Fsc1) em três cucurbitáceas e verificar a reação de genótipos de Cucurbita spp. ao fungo visando seu uso como porta-enxerto. Realizaram-se quatro experimentos. No experimento um, foi avaliado a virulência do Fsc1 em melão, melancia e Cucurbita spp. Nos experimentos dois e três foi analisada a severidade do patógeno em 19 cucúrbitas. E no experimento quatro avaliou a compatibilidade desses genótipos como porta-enxerto para melancia. Cucurbita spp. mostrou-se mais resistente ao Fusarium solani f. sp. cucurbitae raça 1 que o melão. Destacaram-se pela alta frequência de plantas resistentes ao Fsc1 os genótipos BGC622, BGC620, BGC567, BGC530, BGC186, BGC381, BGC692, BGC082, ES0061 e ES0062. Além disso, os genótipos avaliados poderão ser utilizados, como porta-enxerto de melancia, com exceção da linhagem ES530 que se mostrou incompatível com a cultivar BRS Opara, mas poderá ser utilizada em programas de melhoramento de abóbora, assim como os demais genótipos resistentes.

Palavras-chave: Patógeno do solo. Enxertia. Germoplasma. Cucurbitáceas.

\footnotetext{
"Corresponding author

${ }^{1}$ Received for publication in $08 / 03 / 2019$; accepted in 02/13/2020.

Paper extracted from research of the Regional Scientific and Technological Development Program, of the first author.

${ }^{2}$ Department of Agricultural Science, Instituto Federal de Educação, Ciência e Tecnologia do Ceará, Crateús, CE, Brazil; joice.simone@ifce.edu.br - ORCID: 0000-0003-3597-2021.

${ }^{3}$ Embrapa Semiárido, Petrolina, PE, Brazil; rita.dias@embrapa.br - ORCID: 0000-0002-5527-3693, pedro.ribeiro@embrapa.br - ORCID: 0000-0003-4894-437X.

${ }^{4}$ Postgraduate Program in Irrigated Horticulture, Universidade do Estado da Bahia, Juazeiro, BA, Brazil; karinabranco92@hotmail.com ORCID:0000-0003-3247-4692.

${ }^{5}$ Postgraduate Program in Plant Genetic Resources, scholarship FAPESB, Universidade Estadual de Feira de Santana, BA, Brazil; tiago_lim.a@hotmail.com - ORCID: 0000-0002-0916-6344.
} 


\section{INTRODUCTION}

Cucurbits stand out in importance from the nutritional, cultural and economic point of view, being grown mainly for human and animal food, with a significant participation in food production. In 2017, the world production of fruits of this family totaled more than 262 million tons, distributed as follows: watermelon (45.1\%), cucumber (31.9\%), melon (12.5\%) and 10.5\% constituted for pumpkins and squashes (FAO, 2017).

In Brazil, the production of melons and watermelons in 2018 totaled more than 2.8 million tons (IBGE, 2019a). There is no information on the national production of pumpkins and other cucurbits, but in the country the agricultural establishments in the survey of 2017 recorded production exceeding 417 thousand tons of pumpkin, 'jerimuns' and squash, and more than 637 thousand tons of the other cucurbits, for example, zucchini, loofa sponge, chayote, gherkin and cucumber (IBGE, 2019b).

The continuous and intensive cultivation of these species in the same place can cause an increase in the density of soilborne pathogens, affecting the quality and productivity of these crops. Among these pathogens, Fusarium solani f. sp. cucurbitae (Fsc), present in practically all areas of cultivation of cucurbits in Brazil, regardless of being irrigated or rainfed, as it is easily disseminated by contaminated seeds, tools and implements, as long as environmental conditions favor the occurrence of the pathogen. Under conditions of high humidity, for example in rainfed cultivation after the rainy season, associated with temperatures between $20^{\circ} \mathrm{C}$ and 28 ${ }^{\circ} \mathrm{C}$, that favor the occurrence of the pathogen (REGO; CARRIJO, 2000).

According to Martyn et al. (1996), most cucurbits are susceptible in the seedling phase to Fsc, which produces resistance structures called chlamydospores, surviving in crop residues, soil and infected seeds, even under adverse environmental conditions for long periods. Two races of this pathogen have been identified based on the specificity of the tissue in which they act. Race 1 infects hypocotyl and branches, causing cortical rot, as well as in ripe fruits, causing dry rot, whereas, race 2 affects only the fruits (TOUSSON; SNYDER, 1961).

Chemical control of Fusarium solani is difficult, although there are products with efficient action, which have restrictions on use, as there is no record recommending its use in cucurbit crops at the Ministry of Agriculture, Livestock and Food Supply. However, other management measures are being studied, such as: crop rotation, solarization. (PÉREZHERNÁNDEZ; PORCEL-RODRÍGUEZ; GÓMEZVÁZQUEZ, 2017), antifungal essential oil (CRUZ et al., 2015; NASCIMENTO; VIEIRA; KRONKA, 2016) and grafting.

Some cucurbits are suitable for use as rootstocks for watermelon, cucumber or melon. Among them, the following can be cited: Cucurbita spp., Lagenaria siceraria, Citrullus spp., Benincasa spp. and Luffa spp. However, the most popular ones are the rootstocks of Cucurbita spp., especially hybrids of $C$. maxima x $C$. moschata, which have been widely used in watermelon, as they provide nonspecific but efficient protection to a wide variety of pathogens, which colonize the root system, and tolerance to abiotic stresses (PICÓ et al., 2017). In addition, some species of the genus Cucurbita spp. and $C$. lanatus var. citroides exhibit greater root development and rusticity, favoring better use of water and nutrients, and increased productivity, without affecting the quality of the grafted cultivar's fruits (SANTOS et al., 2016).

The use of genetic resistance for soilborne pathogens is one of the most important technological advances in agriculture. In this context, the adoption of grafting can be a short-term and viable strategy to solve problems related to soil pathogens. Based on genotypes from the Active Cucurbit Germplasm Bank (BGC) and from Embrapa Semiárido breeding programs, Cucurbita spp. and $C$. lanatus var. citroides were selected for resistance to soil pathogens and with potential for watermelon rootstock, considering increases in fruit productivity and quality (GAMA et al., 2013; SANTOS et al., 2014; SANTOS et al., 2016).

In view of the grafting potential in commercial watermelon crops in Brazil, due to problems related to soil-dwelling pathogens, it is necessary to identify sources of resistance to such pathogens in the germplasm of Cucurbita spp. In this context, the objective of this work was to evaluate the virulence of Fsc race 1, in three cucurbits, and the reaction of Cucurbita spp. to Fsc1 aiming at its use as rootstock.

\section{MATERIALS AND METHODS}

The four experiments were conducted in a greenhouse at Embrapa Semi-arid, in the municipality of Petrolina-PE, Brazil, from March 2017 to June 2018. The genotypes came from the Active Cucurbit Germplasm Bank for Northeast Brazil and belonged to the breeding collection of Cucurbita spp. (BGC) of Embrapa Semi-Arid. An isolate of Fsc1, from the Phytopathology Laboratory of Fungi Collection of Embrapa Semi-Arid, obtained from pumpkin plant with symptoms of stem rot, was used. The genotypes were planted in pots containing $500 \mathrm{~mL}$ of a commercial substrate for vegetables, in randomized blocks with 20 replicates (Experiment 1) and 10 replicates (Experiments 2, 3 and 4), the experimental unit consists of one plant.

In experiments 1 and 3 , inoculation occurred at 10 days after planting, when the plants had one true leaf, while in experiment 2 , inoculation occurred 
at 45 days after sowing, when the plants had three or four true leaves. In the inoculations, there was a difference of age of the plants in the experiments 2 and 3, to verify if the reaction of the plants to Fsc1 was influenced by their stage of development.

a) Experiment 1

To assess the virulence of Fsc1, three species of cucurbits, previously established as susceptible, were inoculated with the fungus: two genotypes of Cucurbita spp. (BGC010 and BGC814), two of melon (cultivar ES0442 and strain ES0371.04) and two of watermelon (ES31654/2 and ES31662/2). For inoculation, the Fsc1 isolate was grown in Potato Dextrose Agar (PDA) medium for 15 days, at $25{ }^{\circ} \mathrm{C}$ and $12 \mathrm{~h}$ photoperiod. Before inoculation, the collar of each seedling was injured by a set of three disinfected 3-mm pins. Then, a disk of culture medium $5 \mathrm{~mm}$ wide, containing structures of the pathogen, was deposited under a cotton ball moistened with sterile water (to promote a humid chamber at the inoculation site), fixing them with aluminum tape around the collar of the plant. The inoculum remained in contact with the injured tissue for $72 \mathrm{~h}$. After inoculation, the plants were kept in a greenhouse at a temperature of $29.9 \pm 3{ }^{\circ} \mathrm{C}$ and $58 \pm$ $2 \%$ relative humidity (experiments 1 and 3 ) and at a temperature of $27.4 \pm 4{ }^{\circ} \mathrm{C}$ and $74 \pm 1 \%$ relative humidity (experiment 2 ). The inoculation method and procedures adopted were similar for all inoculations.

b) Experiments 2 and 3

After evaluating the virulence of the pathogen, experiments 2 and 3 were carried out to evaluate the reaction of Cucurbita spp. to Fsc1. In experiment 2, carried out in March 2017, 11 genotypes were evaluated, seven of $C$. maxima: BGC010, BGC685, BGC381, BGC249, BGC622, BGC082, BGC385; and four of C. moschata: BGC567, BGC530, BGC830, BGC814. In experiment 3, carried out in September 2017, we evaluated 17 genotypes of Cucurbita spp.: two commercial genotypes (hybrid ES0061 and variety ES0062) and 15 genotypes of BGC (eight of $C$. maxima: BGC010, BGC685, BGC381, BGC249, BGC622, BGC692, BGC495, BGC447; six of $C$. moschata: BGC567, BGC 530, BGC830, BGC814, BGC620, BGC186; and an experimental hybrid of $C$. maxima x C. moschata: ES0030).

At eight and twenty two days after inoculation, in experiments 2 and 3, respectively, the following parameters were measured: the length and width of the lesions, using a millimeter ruler; the depth of the lesion, assessed by a scale of scores from 1 to 3 (score $1=$ superficial lesion; $2=$ intermediate lesion and 3 = deep lesion, reaching the conducting vessels) and the severity of the disease was also assessed, adopting a scale of scores from 1 to 5, adapted from Preisigke (2014): $1=$ plant without symptoms - highly resistant (HR); $2=$ lesion with less than $50 \%$ of the circumference of the hypocotyl, without of depression, without soaking or moisture within the lesion, as well as without strangulation of the hypocotyl - resistant (R); $3=$ lesion with more than $50 \%$ of the circumference of the hypocotyl, but without strangulation, depressed or not, with soaking or moisture - moderately resistant (MR); $4=$ destruction of the cortex and strangulation of the hypocotyl - susceptible (S); and 5 = dead plant - highly susceptible (HS). The assessments of severity in experiments 2 and 3 were carried out when more than $50 \%$ of BGC010 plants (susceptibility previously known) have reached the score 4 (susceptible).

c) Experiment 4

To evaluate the compatibility of Cucurbita spp. resistant to Fsc1 as a rootstock for watermelon, seven genotypes were evaluated (ES567, ES620, ES530, ES0061, ES0062, ES0007 and ES0012) as a rootstock for the BRS Opara watermelon cultivar. Additionally, this cultivar was evaluated without grafting and under autografting, totaling nine treatments, with 10 repetitions and the experimental unit consisting of one plant. It is of fundamental importance in the selection of the rootstock that it is compatible with the cultivar to be grafted.

The planting of the genotypes used as rootstock was carried out four days after the planting of the scion cultivar, due to the vigor of the pumpkins. At nine days after sowing, when the plants had the first true leaf, grafting was carried out using the approach method. This method consisted of making a diagonal cut from top to bottom in the rootstock hypocotyl and from bottom to top in the hypocotyl of the cultivar to be grafted. Then, the two seedlings were joined and fixed with devices made with aluminum foil (replacing the grafting clips). After this procedure, the grafted plants were transferred to plastic cups of $150 \mathrm{~mL}$ with small holes at the bottom, containing the commercial substrate for vegetables Tropstrato ${ }^{\mathbb{R} \text {. }}$

The seedlings were kept in a greenhouse, at $25^{\circ} \mathrm{C} \pm 1.0$ and $65 \% \mathrm{RH} \pm 1.0$, for seven days, when "weaning" was performed (cutting the root system of the grafted cultivar and eliminating the aerial part of the rootstock). As a preventive phytosanitary control, $0.25 \mathrm{~mL} . \mathrm{L}^{-1}$ of Difenoconazole was applied. The following day after weaning, the surviving plants were placed in a pot with a capacity of 10 liters of soil, containing soil + cattle manure, in a $3: 1$ ratio.

The plants were evaluated for: seedling survival index after weaning (SIW), by counting the seedlings that survived 24 hours after the elimination of the root system of the scion and the aerial part of the rootstock, and estimating the percentage in relation to the total grafted; seedling survival index after transplantation (SWT), by counting the plants that remained alive up to 30 days after transplanting, and estimating the percentage in relation to the total of plants that were submitted to transplantation; and total survival index, by the sum of SIW and SWT. 
The development of plants was also evaluated through the variables: length of the main branch, with the use of measuring tape; precocity, considering the period from sowing to the anthesis of the first male and female flower; and dry mass of plants, where the plants (root + branch + leaves + flowers) were placed in paper bags and dried in an oven, at $63{ }^{\circ} \mathrm{C}$, for $120 \mathrm{~h}$. The dry mass was determined on an electronic scale with an accuracy of $0.001 \mathrm{~g}$.

The data obtained in the evaluations were subjected to analysis of variance and the means were compared by the Tukey test, at 5\% significance level. In experiments 2 and 3 Pearson's correlation coefficients were estimated between the variables: length, width and depth of the lesion and disease severity scale. Descriptive statistics was applied to group the genotypes in resistance classes and to analyze the frequency of plants within each score. For the analysis of variance, Sisvar ${ }^{\circledR}$ software version 5.6 (FERREIRA, 2015) was used and Pearson's correlation coefficient was estimated by SPSS $^{\circledR}$ (IBM SPSS Statistics for Windows, version 20.0, 2011, USA).

\section{RESULTS AND DISCUSSION}

When inoculating different species of cucurbits with the fungus, it was observed that the melon was more sensitive to the inoculum of Fsc1 than the genotypes of Cucurbita spp. but the severity of the watermelon inoculum was similar to that of melon and Cucurbita spp. (Figure 1), demonstrating the virulence of the pathogen and the wide range of hosts within the cucurbits.

Corroborating with the present study, Nagao, Sato and Ogiwara (1994), when submitting genotypes of Cucurbita spp. and Cucumis sativus to different isolates, observed that cucumber was less susceptible to Fsc1 than the species of the genus Cucurbita spp. These results suggest the existence of different reactions of cucurbit species to Fsc1. Thus, genotypes can respond differently to different isolates, depending on the variability in the degree of virulence of Fsc1 populations, the environment (temperature, abiotic stresses, among others) and the age of the plant.

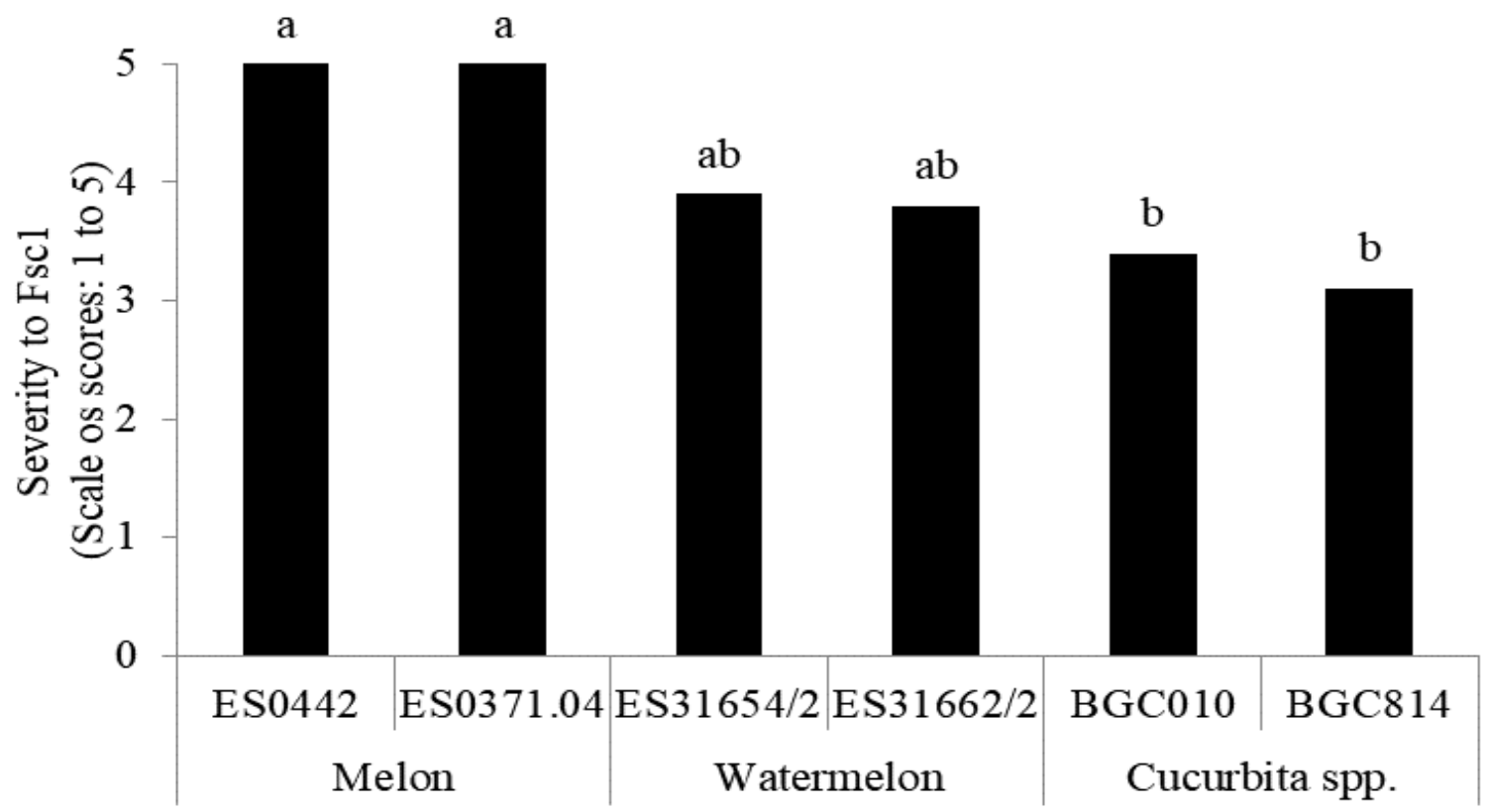

Figure 1. Reaction of melon, watermelon and Cucurbita spp. to Fusarium solani f. sp. cucurbitae race 1. Bars with the same letters do not differ according to Tukey's test at the 5\% probability level. Score scale from 1 to 5 (where: $1=$ highly resistant plants; $2=$ resistant; $3=$ moderately resistant; $4=$ susceptible and $5=$ highly susceptible plant).

In 26 isolates of Fsc1 from watermelon, melon and cucumber at different growth stages, grown in different locations, great genetic diversity was observed among the isolates, with the formation of 10 similarity groups, with no correlation with geographic origin or species (ALYMANESH et al., 2009). In addition, it must be considered that there may be genetic variability, for resistance or tolerance to Fusarium solani, between and within species, as found by Anjos et al. (2018) in genotypes of

\section{Capsicum spp.}

(Table 1) shows the results of the severity of the Fsc1 lesion in the genotypes of Cucurbita spp. in experiments 2 and 3. For the analyzed variables, different responses were found between the genotypes as a function of the experiment. In general, the lesion length was higher in the plants evaluated in experiment 2 , than in those inoculated in experiment 3 . 
Table 1. Reaction of Cucurbita spp. Genotypes to Fusarium solani f. sp. cucurbitae race 1 in two inoculation seasons.

\begin{tabular}{|c|c|c|c|c|c|c|}
\hline \multirow{3}{*}{ Genotypes } & \multicolumn{6}{|c|}{ Lesion size } \\
\hline & \multicolumn{2}{|c|}{ Length $(\mathrm{cm})$} & \multicolumn{2}{|c|}{ Diameter $(\mathrm{cm})$} & \multicolumn{2}{|c|}{ Depth ('scores) } \\
\hline & E2 & E3 & E2 & E3 & E2 & E3 \\
\hline BGC010 & $1.34 \mathrm{bc}$ & $0.52 \mathrm{c}$ & $0.44 \mathrm{~cd}$ & $0.50 \mathrm{a}$ & $1.8 \mathrm{~cd}$ & $1.5 \mathrm{bc}$ \\
\hline BGC685 & $2.27 \mathrm{a}$ & $0.57 \mathrm{c}$ & $0.86 \mathrm{a}$ & $0.32 \mathrm{def}$ & $2.7 \mathrm{a}$ & $1.2 \mathrm{~cd}$ \\
\hline BGC381 & $1.11 \mathrm{~cd}$ & $1.04 \mathrm{a}$ & $0.57 \mathrm{bc}$ & $0.35 \mathrm{cdef}$ & $2.1 \mathrm{bcd}$ & $1.1 \mathrm{~cd}$ \\
\hline BGC249 & $0.97 \mathrm{~cd}$ & $1.01 \mathrm{a}$ & $0.41 \mathrm{~cd}$ & $0.31 \mathrm{def}$ & $1.7 \mathrm{~cd}$ & $1.0 \mathrm{~d}$ \\
\hline BGC622 & $0.84 \mathrm{~d}$ & $0.71 \mathrm{bc}$ & $0.35 \mathrm{~d}$ & 0.32 def & $1.8 \mathrm{~cd}$ & $1.0 \mathrm{~d}$ \\
\hline BGC082 & $1.04 \mathrm{~cd}$ & - & $0.34 \mathrm{~d}$ & - & $1.9 \mathrm{~cd}$ & - \\
\hline BGC385 & $1.58 \mathrm{~b}$ & - & $0.63 \mathrm{~b}$ & - & $2.4 \mathrm{ab}$ & - \\
\hline BGC692 & - & $0.16 \mathrm{~d}$ & - & $0.35 \mathrm{cdef}$ & - & $1.1 \mathrm{~cd}$ \\
\hline BGC495 & - & $0.48 \mathrm{c}$ & - & $0.46 \mathrm{ab}$ & - & $1.5 \mathrm{bc}$ \\
\hline BGC447 & - & $0.52 \mathrm{c}$ & - & $0.32 \mathrm{def}$ & - & $1.0 \mathrm{~d}$ \\
\hline BGC567 & $1.14 \mathrm{bcd}$ & $0.57 \mathrm{c}$ & $0.44 \mathrm{~cd}$ & $0.26 \mathrm{f}$ & $2.2 \mathrm{bc}$ & $1.3 \mathrm{~cd}$ \\
\hline BGC530 & $1.14 \mathrm{bcd}$ & $0.60 \mathrm{c}$ & $0.40 \mathrm{~d}$ & $0.35 \mathrm{cdef}$ & $1.2 \mathrm{e}$ & $1.0 \mathrm{~d}$ \\
\hline BGC830 & $1.09 \mathrm{~cd}$ & $0.86 \mathrm{ab}$ & $0.35 \mathrm{~d}$ & $0.39 \mathrm{bcd}$ & $1.2 \mathrm{e}$ & $1.5 \mathrm{bc}$ \\
\hline BGC814 & $1.16 \mathrm{bcd}$ & $0.61 \mathrm{c}$ & $0.39 \mathrm{~d}$ & $0.44 \mathrm{abc}$ & $1.6 \mathrm{de}$ & $2.1 \mathrm{a}$ \\
\hline BGC620 & - & $0.58 \mathrm{c}$ & - & $0.29 \mathrm{ef}$ & - & $1.0 \mathrm{~d}$ \\
\hline BGC186 & - & $0.68 \mathrm{bc}$ & - & 0.37 bcde & - & $1.5 \mathrm{bc}$ \\
\hline ES0062 & - & $0.54 \mathrm{c}$ & - & $0.34 \mathrm{def}$ & - & $1.1 \mathrm{~cd}$ \\
\hline ES0030 & - & $0.96 \mathrm{a}$ & - & 0.38 bcde & - & $1.9 \mathrm{ab}$ \\
\hline ES0061 & - & $0.68 \mathrm{bc}$ & - & $0.27 \mathrm{f}$ & - & $1.0 \mathrm{~d}$ \\
\hline $\mathrm{CV}(\%)$ & 36.6 & 21.9 & 34.3 & 16.8 & 25.1 & 22.0 \\
\hline
\end{tabular}

Means followed by same letters in a column do not differ according to Tukey's test at the 5\% probability level. "-"noninoculated genotypes. ${ }^{1}$ Score scale ranged from 1 to 3 ( $1=$ superficial lesion; $2=$ intermediate lesion and $3=$ deep lesion, reaching the conducting vessels). E2 = experiments 2 (March 2017) and E3 = experiment 3 (September 2017).

Shorter length of the lesion on the plant collar was observed, in experiment 2, in BGC381, BGC249, BGC082, BGC567, BGC530, BGC830, BGC814 and BGC622, and the last-mentioned stood out with $0.84 \mathrm{~cm}$, as well as BGC962 in experiment $3(0.16 \mathrm{~cm})$. On the other hand, greater lesion length was observed in the genotypes BGC685 (experiment 2), and BGC249, BGC381, BGC830 and ES0030 (experiment 3 ). Approximately $82 \%$ and $77 \%$ of the genotypes had lesion length with intermediate size when inoculated with Fsc1 in experiments 2 and 3, respectively.

The length of the lesion is an important parameter in the evaluation of Fsc1, as it is one of the characteristic symptoms of the disease and after artificial inoculation there is the appearance of lesions in the plant tissue with longitudinal cracks, especially in the collar. Although the inoculation in experiment 3 occurred in plants with younger age, in general, they showed shorter lesion length. Different isolates can produce different amounts of toxic metabolites, being expressed, indirectly, by the intensity of the induced symptoms. This does not apply to the present study, since the same Fsc1 isolate was used. Antonio et al. (2019) when evaluating different genotypes of melon inoculated with Fusarium solani found lesions ranging from 1.09 to $4.10 \mathrm{~cm}$, being classified as moderately resistant and highly susceptible, respectively.

It was found that, in experiment 2, the accessions BGC530, BGC830, BGC814, BGC622, BGC082, BGC010, BGC249 and BGC567 stood out with a smaller lesion diameter, varying from 0.34 to $0.44 \mathrm{~cm}$ (Table 1), whereas BGC685 had larger diameter $(0.86 \mathrm{~cm})$. In experiment 3 , a smaller diameter of the lesion was observed in $70.6 \%$ of the genotypes, ranging from $0.26 \mathrm{~cm}$ to $0.35 \mathrm{~cm}$. In this trial, BGC010, BGC495 and BGC 814 exhibited the largest diameter of the lesion, ranging from $0.44 \mathrm{~cm}$ to $0.50 \mathrm{~cm}$. In kiwi fruits, lesions with a diameter of $20 \mathrm{~mm}$ were observed nine days after inoculation with Fusarium solani, which later covered the whole fruit (YANG et al., 2018).

The diameter of the lesion caused by Fsc1 in plant tissues is a characteristic that can define the severity of the disease, because the greater its width, the greater the possibility of collar constriction, which may result in plant collapse. However, in Cucurbita spp. there are no reports available that associate the width of the lesion with the severity of the disease in seedlings inoculated with the studied fungus, as both plants classified by scale of grades as resistant and those classified as susceptible exhibited similar lesion widths.

The genotypes BGC530 and BGC830, inoculated in experiment 2 , showed superficial lesion without tissue depression (score 1.2), whereas in BGC685 and BGC385 the lesions were deep with scores 2.7 and 2.4, respectively (Table 1). In experiment 3, approximately $64.7 \%$ of accessions (BGC530, BGC249, BGC622, BGC620, BGC447, BGC685, BGC381, BGC692, BGC567, ES0062 and ES0061) exhibited mild lesions with no depression (score 1.0 to 1.3). The genotypes BGC814 and 
ES0030 had the higher score for lesion depth $(2.1$ and 1.9).

The deeper the lesion on the plant stem caused by the inoculation of Fsc1, the greater the possibility of it reaching the vascular system, which, when damaged or broken, compromises the flow of water and nutrients, resulting in wilting, yellowing and death of the plant. In the recent literature, there are no studies evaluating the depth of the lesion in the collar of the plant caused by Fsc1 in Cucurbita spp. However, Wang et al. (2014) observed that, during storage, sweet potato roots with Fusarium solani developed slightly concave lesions on the surface, but when cutting these roots, they found that the lesions could extend to the center of the organ.

In ripe melon fruits inoculated with four Fsc1 isolates from different locations, it was observed that the maximum depth of the lesion varied from $3.0 \mathrm{~cm}$ to $3.4 \mathrm{~cm}$ (CHAMPACO; MARTYN; MILLER, 1993). Also, according to these authors, an Fsc1 isolate can be weakly pathogenic in seedlings and highly aggressive to fruits. However, most cultivated cucurbits are sensitive to the fungus in the seedling phase (ABDUL-HASAN; HUSSEIN, 2016). In addition, melon appears to be more sensitive to Fsc1 than Cucurbita spp. Considering that the tissues found in the stem of pumpkin seedlings are more lignified than those of most commercial melon seedlings, probably those that have greater difficulty for penetration than melon seedlings, which are more easily degraded and more vulnerable to the action of the fungus.

The results of Fsc1 severity and plant frequency regarding resistance in the genotypes of Cucurbita spp. in two experiments are found in (Table 2). For the plants inoculated in experiment 2, it was found that the accessions BGC530, BGC082, BGC249, BGC622, BGC830 and BGC010 showed the lowest severity of the disease (average score from 2.0 to 2.4) (Table 2). The BGC685 access showed the highest average score (5.0) for disease severity, with $100 \%$ of plants showing a high susceptibility reaction to Fsc1. In 14 cultivars of zucchini, grown in different cycles, for 20 months, in bags with pearlite infested with Fsc1, it was found that, although the severity of the disease was significantly reduced after 14 months, all genotypes were highly susceptible to the disease (PÉREZHERNÁNDEZ; PORCEL-RODRÍGUEZ; GÓMEZVÁZQUEZ, 2017).

Table 2. Severity (S) and frequency of reaction of Cucurbita spp. to Fusarium solani f. sp. cucurbitae race 1 in two inoculation periods: experiment 2 and experiment 3.

\begin{tabular}{|c|c|c|c|c|c|c|c|c|c|c|c|c|}
\hline \multirow{3}{*}{${ }^{1}$ Genotypes } & \multicolumn{6}{|c|}{ Experiment 2} & \multicolumn{6}{|c|}{ Experiment 3} \\
\hline & \multirow{2}{*}{$\begin{array}{c}\mathrm{S} \\
\left({ }^{1} \text { Scores }\right)\end{array}$} & \multicolumn{5}{|c|}{ Resistance (\%) } & \multirow{2}{*}{$\begin{array}{c}\mathrm{S} \\
\left({ }^{1} \text { Scores }\right) \\
\end{array}$} & \multicolumn{5}{|c|}{ Resistance (\%) } \\
\hline & & $\mathrm{AR}$ & $\mathrm{R}$ & MR & $\mathrm{S}$ & $\mathrm{AS}$ & & $\mathrm{AR}$ & $\mathrm{R}$ & MR & $\mathrm{S}$ & $\mathrm{AS}$ \\
\hline BGC685 & $5.0 \mathrm{a}$ & 0.0 & 0.0 & 0.0 & 100 & 0.0 & $2.4 \mathrm{abc}$ & 0.0 & 80.0 & 10.0 & 0.0 & 10.0 \\
\hline BGC381 & $3.8 \mathrm{~b}$ & 0.0 & 33.3 & 0.0 & 22.2 & 44.4 & $2.0 \mathrm{bc}$ & 0.0 & 91.7 & 8.3 & 0.0 & 0.0 \\
\hline BGC385 & $3.5 \mathrm{~b}$ & 0.0 & 46.9 & 3.1 & 0.0 & 50.0 & - & - & - & - & - & - \\
\hline BGC814 & $3.4 \mathrm{bc}$ & 4.2 & 25.0 & 29.2 & 12.5 & 29.2 & $3.2 \mathrm{ab}$ & 0.0 & 30.0 & 40.0 & 10.0 & 20.0 \\
\hline BGC567 & $2.8 \mathrm{~cd}$ & 0.0 & 60.0 & 20.0 & 0.0 & 20.0 & $2.1 \mathrm{bc}$ & 0.0 & 92.3 & 7.7 & 0.0 & 0.0 \\
\hline BGC830 & $2.4 \mathrm{de}$ & 15.8 & 57.9 & 5.3 & 10.5 & 10.5 & $2.5 \mathrm{abc}$ & 0.0 & 50.0 & 50.0 & 0.0 & 0.0 \\
\hline BGC010 & $2.6 \mathrm{de}$ & 0.0 & 0.0 & 5.9 & 76.5 & 17.6 & $3.4 \mathrm{a}$ & 10.0 & 20.0 & 20.0 & 20.0 & 30.0 \\
\hline BGC249 & $2.0 \mathrm{e}$ & 0.0 & 100 & 0.0 & 0.0 & 0.0 & $2.2 \mathrm{abc}$ & 28.6 & 57.1 & 0.0 & 0.0 & 14.3 \\
\hline BGC622 & $2.0 \mathrm{e}$ & 0.0 & 100 & 0.0 & 0.0 & 0.0 & $2.3 \mathrm{abc}$ & 0.0 & 90.0 & 0.0 & 0.0 & 10.0 \\
\hline BGC082 & $2.1 \mathrm{e}$ & 0.0 & 94.1 & 5.9 & 0.0 & 0.0 & - & - & - & - & - & - \\
\hline BGC530 & $2.1 \mathrm{e}$ & 3.7 & 85.2 & 11.1 & 0.0 & 0.0 & $2.1 \mathrm{bc}$ & 0.0 & 92.3 & 7.7 & 0.0 & 0.0 \\
\hline BGC692 & - & - & - & - & - & - & $2.0 \mathrm{bc}$ & 0.0 & 92.9 & 7.1 & 0.0 & 0.0 \\
\hline BGC495 & - & - & - & - & - & - & $3.2 \mathrm{ab}$ & 0.0 & 41.7 & 16.7 & 8.3 & 33.3 \\
\hline BGC447 & - & - & - & - & - & - & $2.3 \mathrm{abc}$ & 0.0 & 63.6 & 27.3 & 0.0 & 9.1 \\
\hline BGC620 & - & - & - & - & - & - & $2.0 \mathrm{bc}$ & 0.0 & 100.0 & 0.0 & 0.0 & 0.0 \\
\hline BGC186 & - & - & - & - & - & - & $2.1 \mathrm{bc}$ & 0.0 & 91.7 & 8.3 & 0.0 & 0.0 \\
\hline ES0062 & - & - & - & - & - & - & $2.0 \mathrm{bc}$ & 0.0 & 100.0 & 0.0 & 0.0 & 0.0 \\
\hline ES0030 & - & - & - & - & - & - & $2.6 \mathrm{abc}$ & 10.0 & 50.0 & 20.0 & 10.0 & 10.0 \\
\hline ES0061 & - & - & - & - & - & - & $1.9 \mathrm{c}$ & 7.1 & 92.9 & 0.0 & 0.0 & 0.0 \\
\hline $\mathrm{CV}(\%)$ & 20.4 & - & - & - & - & - & 33.4 & - & - & - & - & - \\
\hline
\end{tabular}

Means followed by same letter do not differ in the same column by Tukey's test at $5 \%$ significance level. ${ }^{1}$ Score scale from 1 to $5(1=$ highly resistant plants (HR) - no symptom; $2=$ resistant plants (R), 3 = moderately resistant plants (MR); 4 $=$ susceptible plants $(\mathrm{S})$ and $5=$ highly susceptible plants $(\mathrm{HS})$. 
Also in experiment 2, a group of medium severity (scores 2.4 to 3.8 ) was formed by $54.5 \%$ of the genotypes. A frequency of plants highly resistant to Fsc1 was found in BGC530 (3.7\%), BGC814 (4.2\%) and BGC830 (15.8\%) (Table 2).

In experiment $3,73.7 \%$ of the genotypes were classified as resistant to Fsc1, with a score of 1.9 to 2.4 (Table 2). In that same experiment, it was possible to observe that BGC620 and ES0062 stood out for showing $100 \%$ of resistant plants. Low frequencies of highly resistant plants were observed in ES0061 (7.1\%), BGC010 (10\%), ES0030 (10\%) and BGC249 $(28.6 \%)$. The promising genotypes with high frequency of resistant plants should be submitted to a selection program under inoculation, followed by self-fertilization to obtain homozygosity of this character. Thus, they can be used as rootstocks for watermelon.

The cultivation of watermelon with the use of resistant rootstocks not only promotes the control of soil pathogens, but can also increase fruit productivity and quality. This increase in watermelon yield can be attributed both to the control of the disease and to the improvement in plant growth, due to the characteristics of vigor and rusticity of the root system, allowing the absorption of a greater amount of nutrients (SANTOS et al., 2016). Other genotypes resistant to Fsc have already been identified in different cucurbits suitable for watermelon rootstock in Citrullus colocynthis and hybrids of $C$. colocynthis x C. lanatus var. citroides (BORGI et al., 2009). C. lanatus var. citroides (BOUGHALLEB et al., 2016) and Cucurbita spp. (BOUGHALLEB et al., 2008).

It was observed that when inoculating the plants in experiment 3 , six of the genotypes showed the same behavior observed when they were inoculated in experiment 2, remaining resistant (BGC249, BGC622 and BGC530) or susceptible (BGC814, BGC830 and BGC010). On the other hand, the genotypes BGC381 and BGC685, which showed a susceptibility reaction in experiment 2 , showed a resistance reaction in experiment 3 (Table 2 ). The greater or lesser susceptibility of a genotype to Fsc1 can vary according to the host-pathogenenvironment interaction. And as already noted by Boughalleb et al. (2005), genotypes may respond differently to different isolates, due to the variability in the degree of virulence of FSC1 populations. Moreover, the environment (temperature, stress etc.) and age of the plant can also interfere in the plants' reaction to the presence of the pathogen.

Thus, in the present work, although the plants of Cucurbita spp. were at different ages at the time of inoculation, four true leaves in experiment 2 and one in experiment 3 , probably, this was not the factor that most contributed to the lower severity of the disease in experiment 3 , since the tender and succulent tissues, exhibited by the seedlings in this experiment, would be more sensitive to the action of the fungus, contrary to what was observed in the results presented. In addition, the same isolate was used in both experiments.

Thus, the divergence regarding the resistance or susceptibility reactions observed for the same genotype in the two inoculations can be attributed to environmental conditions, where the temperature of $27.4 \pm 4{ }^{\circ} \mathrm{C}$ and $74 \pm 1 \% \mathrm{RH}$ (experiment 2 ) favored the action of the fungus during the inoculation period, while at a temperature of $29.9 \pm 3{ }^{\circ} \mathrm{C}$ and 58 $\pm 2 \% \mathrm{RH}$ it promoted a reduction in the severity of Fsc1 (experiment 3). According to Rego and Carrijo (2000), temperatures between $20{ }^{\circ} \mathrm{C}$ and $28{ }^{\circ} \mathrm{C}$ associated with high humidity are conditions that favor the occurrence of the pathogen. Similar results to that observed in the present study were found in soybean, in Paraná, in two inoculation periods: July / 2002 and September / 2002, where there was a difference in the intensity of the symptoms of $F$. solani f. sp. glycine between the two periods of experimentation, and the severity of the disease in the second one was lower than that of the first experiment (KLINGELFUSS; YORINORI; DESTRO, 2007), demonstrating the effect of environmental factors on this characteristic.

For Cucurbita pepo grown in greenhouses, $97.2 \%$ of the plants exhibited symptoms of SCF and, later, $70.8 \%$ of these died at an average temperature of $29{ }^{\circ} \mathrm{C}$ (PÉREZ-HERNÁNDEZ; PORCELRODRÍGUEZ; GÓMEZ-VÁZQUEZ, 2017). Thus, occurrence of high temperatures, humidity and mild night temperatures, as well as plants stressed by weather conditions, nutritional problems and / or attack of other pathogens, associated with damaged tissue, are factors contributing to the incidence of Fsc.

Pearson's correlations between the variables showed different behavior depending on the experiment. In experiment 2, even with the low magnitude in the correlation coefficient, the scale of scores used to assess the severity of the disease was significant and positive only with the depth of the lesion. However, the length showed a positive and significant correlation with the width and depth of the lesion (Table 3). 
Table 3. Correlation between the length, diameter and depth of the lesion, and the score scale used for the evaluation of Fsc1severity in Cucurbita spp. genotypes submitted to two inoculation periods: experiment 2 (E2) and experiment 3 (E3).

\begin{tabular}{|c|c|c|c|c|}
\hline & Experiment & Diameter $(\mathrm{cm})$ & Depth (cm) & ${ }^{2}$ Scale of scores \\
\hline \multirow{2}{*}{ Lesion length $(\mathrm{cm})$} & E2 & $0.76^{* *}$ & $0.62 * *$ & $0.11 \mathrm{~ns}$ \\
\hline & E3 & $0.11 \mathrm{~ns}$ & $0.19 *$ & $0.81 * *$ \\
\hline \multirow{2}{*}{ Lesion diameter $(\mathrm{cm})$} & E2 & & $0.68 * *$ & $0.11 \mathrm{~ns}$ \\
\hline & E3 & & $0.22 * *$ & $0.15 *$ \\
\hline \multirow{2}{*}{ Lesion depth ( ${ }^{1}$ score) } & E2 & & & $0.31 * *$ \\
\hline & E3 & & & $0.25 * *$ \\
\hline
\end{tabular}

*The correlation is significant at $\mathrm{p}<0.05$. ${ }^{* *}$ The correlation is significant at $\mathrm{p}<0.01$. ns the correlation is not significant. ${ }^{1}$ Score scale ranged from 1 to 3 (where: $1=$ no depression of lesion; $2=$ very deep, and $3=$ very deep. ${ }^{2}$ Score scale ranged from 1 to 5 [where 1 = highly resistant plant (HR); $2=$ resistant plant $(\mathrm{R}), 3=$ moderately resistant plant $(\mathrm{MR}), 4=$ susceptible plant (S) and $5=$ highly susceptible plant (HS)]. Experiments 2 and 3 (E2 and E3).

In experiment 3, the score scale adopted for disease severity exhibited significant and positive correlations with the length (high correlation), the width and depth of the lesion. Nagao, Sato and Ogiwara (1994) evaluated the severity of Fsc1 by a scale of scores in genotypes of Cucurbita spp. and Cucumis sativus, associating susceptibility to the disease with severe infection of the hypocotyl, root discoloration and plant death. In melon germplasm, the reaction of susceptibility to Fscl was also assessed by a scale of scores, associated with the visual aspect of the lesion size and stem constriction (GUIMARÃES, 2016). Galon (2013), when evaluating 33 genotypes of cucurbits submitted to two distinct inoculants of $\mathrm{Fsc} 1$, considered as susceptible plants those that exhibited severe wilting, chlorosis and leaf necrosis and death.
Thus, it can be inferred that the score scale used in the present work proved to be effective in distinguishing susceptible and resistant plants, resulting in the optimization of the process of selection of resistant plants by trained people, especially when the goal is to evaluate a large number of plants. However, measuring the width and length of the lesion per plant, despite taking time, making the selection process slow and costly, is a more objective assessment.

Compatibility data revealed that BRS Opara under self-grafting (OP / SG) and three scion / rootstock combinations, both after weaning (OP / ES567, OP / ES530 and OP / ES0007) and after transplanting (OP / ES620, OP / ES0007 and OP / ES0061), obtained $100 \%$ seedling survival (Table 4).

Table 4. Seedling survival, precocity, length of main branch (LMB) and dry mass of plant (DMP) of BRS Opara watermelon after grafting on different rootstocks of Cucurbita spp.

\begin{tabular}{|c|c|c|c|c|c|c|c|}
\hline \multirow{2}{*}{ Scion / rootstock } & \multicolumn{3}{|c|}{ Seedling survival (\%) } & \multicolumn{2}{|c|}{$\begin{array}{l}{ }^{1} \text { Precocity } \\
\text { (DAS) }\end{array}$} & \multirow{2}{*}{$\begin{array}{c}{ }^{1} \mathrm{LMB} \\
(\mathrm{cm})\end{array}$} & \multirow{2}{*}{$\begin{array}{c}{ }^{1} \mathrm{DMP} \\
(\mathrm{g})\end{array}$} \\
\hline & AW & AT & Total & MF & $\mathrm{FF}$ & & \\
\hline $\mathrm{OP} / \mathrm{WG}$ & - & - & 100.0 & $40.3 \mathrm{e}$ & $47.1 \mathrm{c}$ & $198.0 \mathrm{a}$ & $22.5 \mathrm{ab}$ \\
\hline $\mathrm{OP} / \mathrm{SG}$ & 100.0 & 100.0 & 100.0 & $43.0 \mathrm{de}$ & $51.4 \mathrm{bc}$ & $176.3 \mathrm{a}$ & $15.9 \mathrm{~cd}$ \\
\hline OP/ES567 & 100.0 & 93.3 & 93.3 & $52.4 \mathrm{a}$ & $56.8 \mathrm{a}$ & $116.5 \mathrm{~d}$ & $10.4 \mathrm{~d}$ \\
\hline OP/ES620 & 88.9 & 100.0 & 88.9 & $50.3 \mathrm{ab}$ & $53.7 \mathrm{ab}$ & $169.3 \mathrm{abc}$ & $18.4 \mathrm{abc}$ \\
\hline OP/ES530 & 100.0 & 27.3 & 27.3 & $49.8 \mathrm{abc}$ & $55.3 \mathrm{ab}$ & $120.1 \mathrm{~cd}$ & $16.0 \mathrm{~cd}$ \\
\hline OP/ES0007 & 100.0 & 100.0 & 100.0 & $50.2 \mathrm{ab}$ & $54.4 \mathrm{ab}$ & $172.1 \mathrm{ab}$ & $18.7 \mathrm{abc}$ \\
\hline OP/ES0012 & 92.3 & 84.6 & 76.9 & $48.2 \mathrm{bc}$ & $52.5 \mathrm{ab}$ & $125.9 \mathrm{bcd}$ & $16.8 \mathrm{bc}$ \\
\hline OP/ES0061 & 83.3 & 100.0 & 83.3 & $46.4 \mathrm{~cd}$ & $52.4 \mathrm{ab}$ & $172.8 \mathrm{ab}$ & $23.2 \mathrm{a}$ \\
\hline OP/ES0062 & 83.3 & 94.4 & 77.8 & $50.0 \mathrm{abc}$ & $55.8 \mathrm{ab}$ & $152.7 \mathrm{abcd}$ & $22.1 \mathrm{abc}$ \\
\hline CV (\%) & - & - & - & 5.5 & 6.1 & 22.4 & 23.6 \\
\hline
\end{tabular}

According to Goto; Santos and Cañizares (2003), in the seedling phase, the low survival rate of the grafted plants, the excessive growth and the rupture of the grafting point indicate incompatibility of the rootstock with the scion. In the post- transplanting phase, the lack of compatibility is expressed with lack of growth and defoliation, premature death of the plant and poor callus formation, characterized by excessive development below or above the grafting region. 
Thus, although OP / ES530 showed 100\% seedling survival after weaning, $72.7 \%$ of the plants died after transplanting. In addition to this, three other combinations, OP / ES567, OP / ES0012 and OP / ES0062, also exhibited seedling mortality after transplanting, but seedling survival rate of less than $70 \%$ was not observed in any of these combinations. Considering the total survival rate of seedlings, the combinations OP / ES567 and OP / ES0007 stood out, with more than $90 \%$ of live plants (Table 4 ).

Gama et al. (2013), when evaluating this same watermelon cultivar under grafting on rootstocks of Cucurbita spp. and Citrullus spp., found seedling survival rates ranging from 60.0 to $85 \%$, where the lowest rates were observed in BRS Opara grafted on Citrullus spp. However, when grafting seedless watermelon cultivars onto rootstocks of Citrullus lanatus var. citroides, Santos et al. (2014) found survival rates of $72.3 \%$ to $96.4 \%$. Hassell, Pat and Levi (2018) also found 90\% seedling survival when grafting watermelon 'Fascination' on rootstock of $C$. lanatus var. citroides. As previously mentioned, the reduced survival rate of seedlings after grafting may characterize the lack of compatibility between the scion and rootstock, with survival rates below $60 \%$ being considered low. Therefore, in the present work, the OP / ES530 combination is probably incompatible.

As for precocity, it was found that in BRS Opara without grafting (OP/WG), male and female flowering occurred at 40 to 47 days after sowing (DAS), respectively, delaying by 03 (male) to 04 days (female) when grafted (Table 4). The male flowering of the plants grafted on the rootstocks of Cucurbita spp. were delayed from 10 (OP/ES530) to 12 days (OP/ES5) in relation to plants without grafting, and from 07 to 09 days, in comparison to plants under self-grafting. In this same condition, female flowering was delayed by 05 (OP/ES0061) to 10 days (OP/ES567), and by 01 to 06 days, compared to plants without grafting and under autografting, respectively.

Santos et al. (2014), observed with the grafting a delay of 09 to 06 days in the female flowering of the seedless watermelon 'RWT8154', while for the cultivar Shadow the delay was three days. The same behavior was also observed by López-Elías et al. (2011), when grafting seedless watermelon plants on Lagenaria siceraria, with an increase of 02 to 04 days for the harvest. This change in flowering is probably due to the plasticity developed by the grafted plants, which, when submitted to the grafting process, reduce the intensity of their development, to use most of the photoassimilates for the healing process and the restoration of the seedling.

The length of the main branch of BRS Opara plants was influenced by the rootstock. In OP/ ES567, OP/ES530 and OP/ES0012, there was a reduction in the length of the main branch of $28.6 \%$ (OP/ES0012) to $33.9 \%$ (OP/ES567), compared to self-grafting. Analyzing growth based on dry mass, OP/ES0061, OP/ES0062, OP/ES0007 and OP/ES620 were analogous to the growth of $\mathrm{OP} /$ without grafting (Table 4). On the other hand, OP / ES567 and OP / ES530 were similar to self-grafting (OP / SG). Suchoff et al. (2019) when evaluating the watermelon 'Melodi' under grafting and nitrogen doses in two seasons, found that the grafting in the rootstocks of $C$. maxima $\mathrm{x} C$. moschata and in Lagenaria spp. in the year 2013promoted a greater number of leaves and length of the branch, while in the year 2014, under the same treatments, there was a reduction in these characteristics for the grafted plants.

The authors attribute these different responses in vegetative growth to the different environmental conditions observed in 2013 and 2014, since the environment is one of the factors that influence the behavior of seedlings after grafting. In the present work, the slower development of the grafted plants may be the result of the deficient union between the parts involved, as a characteristic of the localized incompatibility. According to Maurya et al. (2019), when there is compatibility between scion and rootstock, there is a rapid development of calluses and formation of vascular bundles, restoring normal plant growth and reducing the mortality rate.

\section{CONCLUSIONS}

Cucurbita spp. was more resistant to Fusarium solani f. sp. cucurbitae race 1 than melon.

The genotypes BGC622, BGC620, BGC567, BGC530, BGC186, BGC381, BGC692, BGC082, ES0061 and ES0062 stood out due to the high frequency of Fsc1-resistant plants.

In addition, the evaluated genotypes can be used as watermelon rootstock, with the exception of the ES530 strain, which was incompatible with the BRS Opara cultivar, but can be used in pumpkin breeding programs, as well as the other resistant genotypes.

\section{ACKNOWLEDGEMENTS}

The authors would like to thank the National Council for Scientific and Technological Development $(\mathrm{CNPq})$ and the Foundation for the Support of Science and Technology of the State of Pernambuco (FACEPE), for funding this study, the Coordination for the Improvement of Higher Education Personnel (CAPES) and the Foundation for the Support to Science and Technology of the State of Bahia (FAPESB), for granting the scholarship to the graduate student, and to Embrapa 
Semiárido for providing the support of infrastructure and personnel to conduct this research.

\section{REFERENCES}

ABDUL-HASAN, F.; HUSSEIN, H. Z. Genetic diversity of Fusarium solani f. sp. cucurbitae. The causal root and crown rot of cucurbits (Melon) by using molecular markers and control. American Journal of Plant Sciences, 7: 21-51, 2016.

ALYMANESH, M. R. et al. Genetic diversity in the fungus Fusarium solani f. sp. cucurbitae race1, the casual agent of root and crown rot of cucurbits in Iran. using molecular markers. Pakistan Journal of Biological Sciences, 12: 836-843, 2009.

ANJOS, I. V. et al. Reação de acessos de Capsicum spp. ao fungo Fusarium solani. Summa Phytopathology, 44: 344-349, 2018.

ANTONIO, R. P. et al. Identificação e mapeamento de QTLs de resistência do meloeiro à podridão do colo causada por Fusarium solani $\mathbf{f}$. sp. cucurbitae. Petrolina: Embrapa Semiárido, 2019. 24 p. (Embrapa semiárido Boletim de pesquisa e desenvolvimento, 138).

BOUGHALLEB, N. M. H. et al. Evaluation of local watermelon and melon rootstocks resistance to six soilborne plant pathogenic fungi in Tunisia. Tunisian Journal of Plant Protection, 11: 191-206, 2016.

BOUGHALLEB, N. et al. Resistance evaluation of grafted watermelon (Citrullus lanatus L.) against fusarium wilt and fusarium crown and root rot. Asian Journal Plant Pathology, 2: 24-29, 2008.

BOUGHALLEB, N. et al. Detection of races 1 and 2 of Fusarium solani f. sp. cucurbitae and their distribution in watermelon fields in Tunisia. Journal of phytopathology, 153: 162-168, 2005.

BORGI, Z. et al. Evaluation of four local colocynth accessions and four hybrids. used as watermelon rootstocks. for resistance to fusarium wilt and fusarium crown and root rot. African Journal of Plant Science and Biotechnology, 3: 37-40, 2009.

CHAMPACO, E. R.; MARTYN, R. D.; MILLER, M. E. Comparison of Fusarium solani and F. oxysporum as causal agents of fruit rot and root rot of muskmelon. HortScience, 28: 1174-1177, 1993.

CRUZ, T. P. et al. Atividade fungicida do óleo essencial de Cymbopogon Winterianus Jowit (Citronela) contra Fusarium solani. Bioscience Journal, 31: 1-8, 2015.
FOOD AND AGRICULTURAL ORGANIZATION OF THE UNITED NATIONS - FAO. FAOSTAT. Production, Crops watermelon, cucumber, melon, pumpkins and Squash. 2017. Available at: < http:// www.fao.org/faostat/en/\#data/QC>. Access: Jun 07, 2019 .

FERREIRA, D. F. Sisvar. Versão 5.6. Lavras: UFLA/DEX, 2015.

GALON, L. A. Enxertia e podridão de raízes e colo em cucurbitáceas. 2013. 55 f. Dissertação (Mestrado em Agronomia: Área de concentração em Produção Vegetal) - Universidade Estadual de São Paulo, São Paulo, 2013.

GAMA, R. N. C. S. et al. Taxa de sobrevivência e desempenho agronômico de melancia sob enxertia. Horticultura Brasileira, 31: 128-132, 2013.

GOTO, R.; SANTOS, H. S.; CAÑIZARES, A. L. Enxertia em hortaliças. 1. ed. São Paulo, SP: UNESP, 2003. 76 p.

GUIMARÃES, I. M. Reação de germoplasmas de melão a Fusarium solani f. sp. cucurbitae e herança da resistência do acesso AC-33 a Monosporascus cannonballus. 2016. 71 f. Tese (Doutorado em Fitotecnia: Área de concentração em Melhoramento de plantas) - Universidade Federal Rural do Semi-árido, Mossoró, 2016.

HASSELL, R. L.; PAT, W.; LEVI, A. Bulldog Citrullus lanatus var. citroides line. a potential rootstock for watermelon grafting. Acta Horticulture, 1204: 219-222, 2018.

INSTITUTO BRASILEIRO DE GEOGRAFIA E ESTATÍSTICA - IBGE. Produção Agrícola Municipal: Lavoura temporária 2018. Available at: <https://sidra.ibge.gov.br/tabela/1612>. Access: Dec 28, 2019a.

INSTITUTO BRASILEIRO DE GEOGRAFIA E ESTATÍSTICA - IBGE. Censo agropecuário 2017. Available at <https://www.ibge.gov.br/estatisticas/ economicas/agricultura-e-pecuaria/21814-2017censo-agropecuario.html $?=\& \mathrm{t}=$ resultados $>$. Access: Dec 28, 2019b.

KLINGELFUSS， L. H.; YORINORI， J. T.; DESTRO, D. Inoculation methods for identification of resistance in soybean to Fusarium solani f. sp. glycines under greenhouse conditions. Fitopatologia Brasileira, 32: 50-55, 2007.

LÓPEZ-ELÍAS, J. et al. Efecto de la densidad de plantación en sandía sin semilla injertada sobre bule (Lagenaria siceraria (Molina) Standl.). Tropical and subtropical agroecosystems, 14: 349-355, 
2011.

MARTYN, R. D. Fusarium crown and foot rot of squash. In: ZITTER, T. A.; HOPKINS, D. L.; THOMAS, C. E. (Eds.). Compendium of Cucurbit Diseases. Saint Paul: American Phytopathological Society, 1996. v. 1, cap. 1, p. 16-17.

MAURYA, D. et al. Grafting techniques in vegetable crops: A review. International Journal of Chemical Studies, 7: 1664-1672, 2019.

NAGAO, H.; SATO, K.; OGIWARA, S. Susceptibility of Cucurbita spp to the cucurbit rootrot fungus, Fusarium solani f. sp. cucurbitae race 1. Agronomie, 14: 95-102, 1994.

NASCIMENTO, D. M.; VIEIRA, G. H. C.; KRONKA, A. Z. Inibição do crescimento micelial de Fusarium solani f. sp. glycines. Revista de Agricultura Neotropical, 3: 65-68, 2016.

\section{PÉREZ-HERNÁNDEZ, A.; PORCEL-} RODRÍGUEZ, E.; GÓMEZ-VÁZQUEZ, J. Survival of Fusarium solani f. sp. cucurbitae and Fungicide Application, Soil Solarization, and Biosolarization for Control of Crown and Foot Rot of Zucchini Squash. Plant Disease, 101: 1507-1514, 2017.

PICÓ, B. et al. Genetic Resources for Rootstock Breeding. In: COLLA, G.; PÉREZ-ALFOCEA, F.; SCHWARZ D. (Eds.). Vegetable Grafting: Principles and Practices, Valencia, ES: CABI, 2017. v. 1, Chapter 2. p. 22-69.

PREISIGKE, S. C. Avaliação de resistência de espécies de Passiflora a patógeno de Solo. 2014. 56 f. Dissertação (Mestrado em Genética e Melhoramento de plantas: área de concentração em MELHORAMENTO VEGETAL) - Universidade do Estado de Mato Grosso, Cacéres, 2014.

REGO, A. M.; CARRIJO, I. V. Doenças das Cucurbitáceas. In: ZAMBOLIM, L.; VALE, F.X.R.; COSTA, H. (Eds.). Controle de doenças de plantas: hortaliças. Viçosa, MG: UFV, 2000, v. 2, p. 535-598.

SANTOS, J. S. et al. Accumulation of nutrients and agronomic performance of grafted seedless watermelon. Pesquisa Agropecuária Tropical, 46: 311-320, 2016.

SANTOS, J. S. et al. Compatibilidade com portaenxertos, rendimento e qualidade de frutos em cultivares de melancia triploide. Revista Caatinga, 27: 141-147, 2014.
SUCHOFF, D. H. et al. Effect of rootstock and nitrogen fertilizer on growth and yield in watermelon. The Journal of Horticultural Science and Biotecnology, 94: 1-7, 2019.

TOUSSON, T. A.; SNYDER, W. C. The pathogenicity, distribution, and control of two races of Fusarium (Hypomyces) solani f. sp.cucurbitae. Phytopathology, 51: 17-22, 1961.

WANG, R. Y. et al. First report of Fusarium solani causing Fusarium root rot and stem canker on storage roots of sweet potato in China. Plant disease, 98: 160-160, 2014.

YANG, C. et al. Fusarium solani, a New Pathogen Causing Postharvest Fruit Rot on Kiwifruit (Actinidia deliciosa) in China. Plant disease, 102: 443-443, 2018. 